\title{
Spectrophotometric Determination of Tetracycline by Azo Dye Formation with Diazotised p-Nitroaniline-Application to Pharmaceutical Preparations and Biological Fluids*
}

\author{
Kasim M.H. Al-Abbasi \\ Department of Chemistry \\ College of Science \\ Mosul University
}

(Received 12/6/2008 ; Accepted 24/11/2008)

\begin{abstract}
This paper involves a spectrophotometric method for the determination of trace amounts of tetracycline in aqueous solution. The method is based on the coupling of tetracycline with diazotized $p$-nitroaniline reagent in basic medium to form a violet mono azo dye that is water - soluble, stable and shows maximum absorption at $569 \mathrm{~nm}$. Beer's law is obeyed over the concentration range $2-400 \mu \mathrm{g} / 25 \mathrm{ml}$ final volume, i.e., $(0.08-16) \mathrm{ppm}$ with a molar absorptivity of $7.8 \times 10^{4} \mathrm{l} \cdot \mathrm{mol}^{-1} \cdot \mathrm{cm}^{-1}$ and sandell sensitivity index of $6.2 \times 10^{-3} \mu \mathrm{g} \mathrm{cm}^{-2}$. The method is applied to the determination of the compound in serum and urine by standard addition method in vitro and in vivo (serum and urine) and pharmaceutical preparation (tetracyclline's ointment).
\end{abstract}

\section{قدير الترلسليكلينطيفيا بتكون صبغة الازومن خلال فترالهمع العالل المؤنوت بارا - ناليترولنلنن وظلبقه عل المستحضرل الصيدلانية والمسولل البليولوجية}

\section{loll}

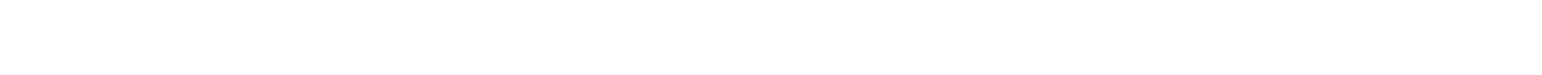

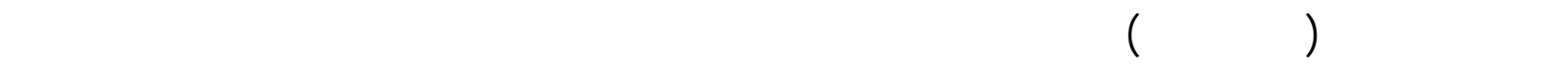

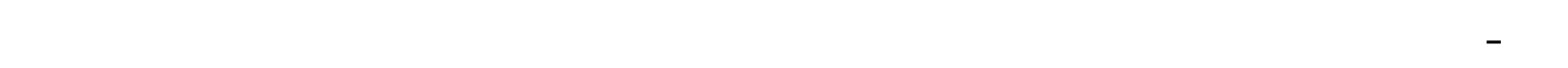
المتصاص عند الطول الموجي (569) نانوميتر وبعد ضبط الظاروف المثلى مت ققدير الدواء بكميت مايكروغرلمية مطقة مع قانون بير وبحدود (2 -400) مايكروغرلم تترلسايكلين في حبه نه الئي

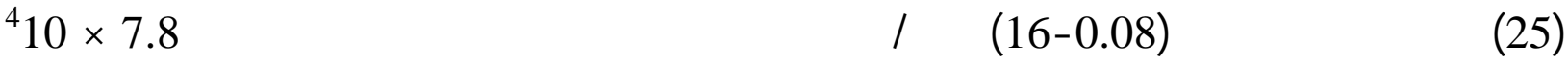

*م إلقاه بالمؤتمر العلي الأول للكيمياء المنعد بتاريخ 22 -23 نيسان 2008 في قنم الكيمياء /كلية العلوم/جلمعة الموصل 


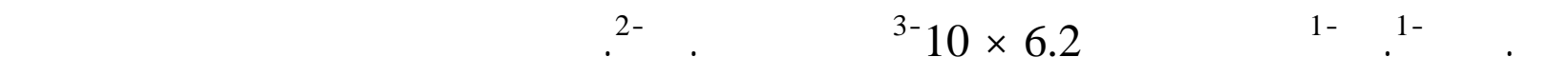

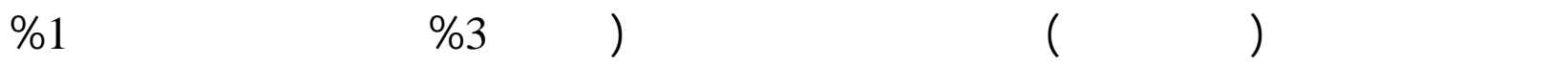

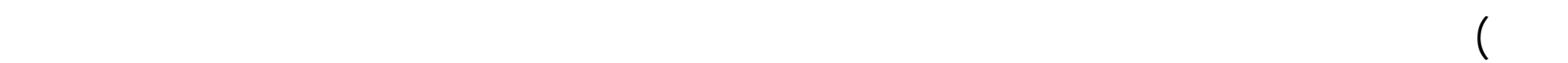

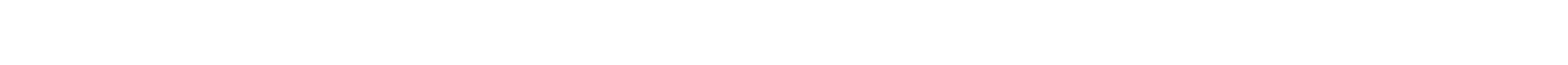

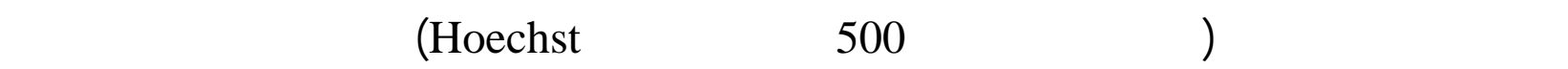

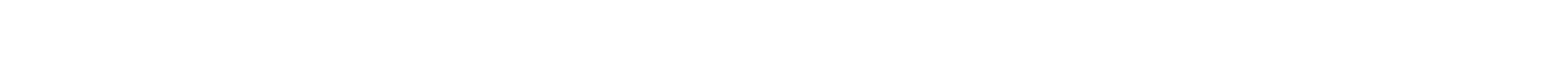
عالمية لقدير المضاد الحيوي في للسوالل البايولوجية بقنية كروماتوغرافيا الغاز وكانت النتائج مطاقِة.

\section{INTRODUCTION}

Tetracycline is the name for the four (tetra) hydrocarbon ring (cycle) derivation (ine) (Wilson et al., 1977).

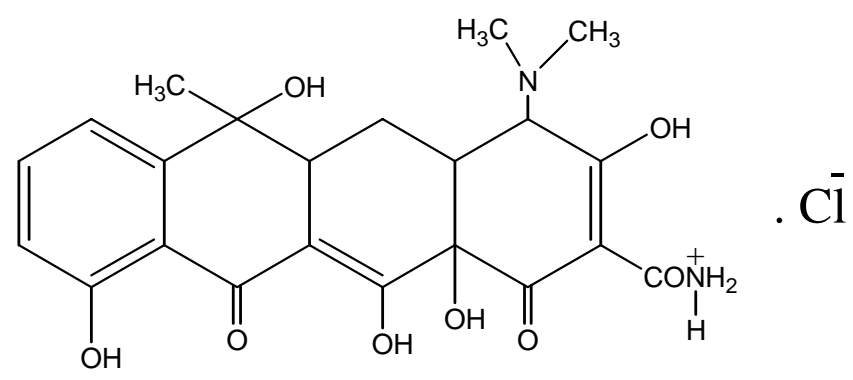

Tetracycline is an effective antibiotic in treating infections (Talaro and Talaro, 1996), and its absorption is reduced by anti-acids and milk, because it can form insoluble complexes with $\mathrm{Ca}, \mathrm{Mg}, \mathrm{Al}$ and $\mathrm{Fe}$ (Alwan and Abou, 1990).

Photometric methods have been suggested for the quantitative estimation of tetracycline. They are based on the measurement of the absorbance of alkaline hydrolysis solution of the antibiotic with iron (III) ions, ammonium molybdate, thorium (IV), concentrated solution of zinc and with diphenylborinic acid. Furthermore, methods are also recommended based on the combination of tetracycline with various diazocompounds, particulary with diazobenzene sulfonic acid (Albert, 1980). Flow injection spectrophotometric determination of tetracycline in a pharmaceutical preparation by complexation with aluminium (III) (Saisunec et al., 2006).

PARAFAC (parallel factor analysis) and PLS (partial least squares) applied to spectrophotoemtric determination of tetracycline in pharmaceutical formation and biological fluids (Ali and Mohammad, 2006).

A spectrophotometric method is described for determination tetracycline hydrochloride reacting with sodium molybdate at the boiling point in hydrochloric aid medium (Sultan, 1986). 
In this research, the method is simple, reproducible and accurate. It is easily applied to determination of the drug in the pure form and in pharmaceutical preparations.

\section{Experimental \\ Apparatus}

Spectral and absorbance measurements are carried out using Shimadzu UV-Visible Recording Spectrophotometer UV-160, with 1-cm matched silica cells.

The pH measurements are performed using Philips PW 9421 pH meter.

\section{Reagents}

All chemicals used are of the highest purity available.

Tetracycline working solution, $100 \mu \mathrm{g} \cdot \mathrm{ml}^{-1}$. A $0.01076 \mathrm{~g}$ amount of tetracycline hydrochloride (Fluka) is dissolved in distilled water and the volume is completed to 100 $\mathrm{ml}$ in a volumetric flask. This solution is kept in a brown bottle.

Diazotised p-nitroaniline solution, 5 mM. A $0.1382 \mathrm{~g}$ of p-nitroaniline (Fluka) is dissolved in about $50 \mathrm{ml}$ of distilled water. Then $1.35 \mathrm{ml}$ of concentrated $\mathrm{HCl}$ is added and the solution is heated. The mixture is transferred to a $200-\mathrm{ml}$ volumetric flask and is cooled to $\approx 5{ }^{\circ} \mathrm{C}$. A $6.9 \mathrm{ml}$ of $1 \% \mathrm{NaNO}_{2}$ is added and the mixture is stirred occasionally for $5 \mathrm{~min}$ and the volume is completed to $200 \mathrm{ml}$ with additional cooled distilled water $\left(5 C^{0}\right)$. This solution is stored in darkness over ice and used after $15 \mathrm{~min}$. This reagent solution when kept in the refrigerator $\left(\approx 5{ }^{\circ} \mathrm{C}\right)$ is stable for at least 3 days.

Sodium hydroxide solution, 5 M. This solution is prepared by dissolving $20 \mathrm{~g}$ of sodium hydroxide in distilled water. Then completing the volume to $100 \mathrm{ml}$ in a volumetric flask with distilled water and transferring it to a plastic bottle.

Cetylpyridinium chloride (CPC) solution, $\mathbf{1 0}^{-3} \mathbf{M}$. This solution is prepared by dissolving 0.0895g in distilled water in a 250-ml volumetric flask.

Serum samples. Blood samples are placed in a water bath $\left(37^{\circ} \mathrm{C}\right)$ for $15 \mathrm{~min}$, and then centrifuged (1000 rpm) for $10 \mathrm{~min}$. to separate serum from whole blood then treated with $2 \mathrm{ml}$ of $1 \mathrm{~N}$ perchloric acid solution to precipitate protein (Al-Molla, 1989). After separation of protein precipitate by centrifugation $(1000 \mathrm{rpm})$ for $10 \mathrm{~min}$., the various volumes of the resulting serum are treated according to recommended procedure for the determination of tetracycline. A $1.5 \mathrm{ml}$ of $\mathrm{NaOH}$ is added instead of $1 \mathrm{ml}$ (the volume in recommended procedure).

Urine samples. After collecting urine samples at different times, each sample is extracted for $10 \mathrm{~min}$. with $5 \mathrm{ml}$ of (3:2) petroleum ether-chloroform (Guyton and Hall, 1996). After layer separation, the organic phase is shaken with $2 \mathrm{ml}$ of $5 \mathrm{M} \mathrm{NaOH}$ for $10 \mathrm{~min}$. to convert the drug into sodium salt which is easily soluble in aqueous layer (Jan, 1980), and then washed with $2 \mathrm{ml}$ distilled water. The resulting aqueous layer is transferred to a $25-\mathrm{ml}$ volumetric flask and the solution is adjusted to the $\mathrm{pH}$ (7.6) of tetracycline standard solution then treated as described in the recommended procedure. 
Ointment samples. Tetracyclline skin and eye ointments contain 3\% and 1\% antibiotic. The ointment sample is dissolved in warm distilled water and the solution is cooled by ice. Then the solution of the tetracycline is collected below wax layer (Al-Abbasi, 1999). The resulting aqueous solution is transferred to a $25-\mathrm{ml}$ volumetric flask and treated as described in the recommended procedure.

\section{RESULTS AND DISCUSSION}

The influence of various reaction variables on the colour development is tested to establish the optimum conditions (stability of the dye resulting from the reaction of tetracycline with diazotised p-nitroaniline in basic medium, intensity of the dye formed, minimum blank values and choice effect of diazotized reagent, diazotized acid, alkaline medium, order of reaction, solvents).

For the subsequent experiments, $50 \mu \mathrm{g}$ of tetracycline is taken in 25-ml final volume and absorbance measurements are performed at $569 \mathrm{~nm}$.

\section{Choice of diazotised reagent}

In order to achieve the optimum spectrophotometric conditions, various diazotised reagents are tested. These reagents are diazotised p-nitroaniline, diazotized $p$-aminobenzophenone, diazotised 2,4-dinitro-aniline and diazotised $p$-aminobenzoic acid. Diazotised $p$-nitroaniline has been selected (Table 1) as an excellent reagent for the determination of tetracycline.

Table 1: Selection of diazotised reagent

\begin{tabular}{|c|c|c|c|c|c|c|}
\hline $\begin{array}{l}\text { Diazotised reagent } \\
\quad(5 \mathrm{mM})\end{array}$ & Structure & $\begin{array}{c}\begin{array}{c}\text { Colour of } \\
\text { diazonium } \\
\text { salt }\end{array} \\
\end{array}$ & Absorbance & $\begin{array}{c}\lambda_{\max }, \\
\mathbf{n m}\end{array}$ & $\begin{array}{r}\varepsilon \times 10^{-4} \\
\text { I.mol } \\
\mathrm{mom}^{-1}\end{array}$ & $\begin{array}{c}\text { Colour } \\
\text { of azo } \\
\text { dye }\end{array}$ \\
\hline$p$-nitroaniline & & $\begin{array}{l}\text { very faint } \\
\text { yellow }\end{array}$ & 0.300 & 569 & 7.2 & violet \\
\hline$p$-aminobenzophenone & & yellow & Turbid & - & - & - \\
\hline 2,4-dinitroaniline & & yellow & 0.051 & 395 & 1.2 & yellow \\
\hline$p$-amino benzoic acid & & colorless & 0.082 & 410 & 1.9 & yellow \\
\hline
\end{tabular}

\section{Effect of diazotisation acid}

The diazotisation reaction proceeds according to the following equation (Al-Abbasi, 1999):

$$
\mathrm{ArNH}_{2}+\mathrm{NaNO}_{2}+2 \mathrm{HX} \stackrel{0-5{ }^{\circ} \mathrm{C}}{\longrightarrow} \mathrm{ArN}_{2} \mathrm{X}+\mathrm{NaX}+2 \mathrm{H}_{2} \mathrm{O}
$$


From the equation above, it seems that the presence of acid for the diazotization reaction is essential. Therefore, the diazotisation of $p$-nitroaniline is carried out in various acids (weak and strong) to establish the suitable acid for the reaction. The results are shown in Table 2.

Table 2: Effect of diazotisation acid on absorbance

\begin{tabular}{|c|c|c|c|c|c|}
\hline \multirow{2}{*}{$\begin{array}{c}\text { Acid used, } \\
\mathbf{1} ~ \mathbf{~ N}\end{array}$} & \multicolumn{5}{|c|}{ Absorbance / ml of diazotised reagent* (5 mM) } \\
\cline { 2 - 6 } & 1 & 3 & 5 & 7 & 9 \\
\hline $\mathbf{H C l}$ & 0.280 & 0.300 & 0.325 & 0.326 & 0.326 \\
\hline $\mathbf{H N O}_{\mathbf{3}}$ & 0.180 & 0.199 & 0.210 & 0.211 & 0.211 \\
\hline $\mathbf{H}_{\mathbf{2}} \mathbf{S O}_{\mathbf{4}}$ & 0.191 & 0.208 & 0.231 & 0.232 & 0.231 \\
\hline
\end{tabular}

* Prepared from the amine and acid in 1:16 ratio.

The experimental data show that acetic acid, phosphoric acid, and formic acid give turbid solution of diazonium salt and after $30 \mathrm{~min}$. a precipitate is formed. Hydrochloric acid gives higher results than others. Therefore, it is regarded as the most suitable of the acids tested.

\section{Effect of amine to acid mole ratio and diazotised reagent amount}

Different ratios (1:1 to $1: 100)$ of amine to hydrochloric acid with different concentrations of diazotised $p$-nitroaniline have been examined for their effect on the yield of the coloured azo dye. The results show that when ratios of amine to acid was lower than 1:4, the solutions of diazonium salt are turbid and the intensity of the coloured azo dye becomes independent of the amine to acid ratio $\geq 8 \mathrm{ml}$ of $5 \mathrm{mM}$ diazotized $p$ nitroaniline added. Therefore, a 1:16 ratio of amine to acid is recommended for subsequent experiments. Higher amounts of acid are undesirable because side reactions may occur (Younis, 1994). A $5 \mathrm{ml}$ of $5 \mathrm{mM}$ diazotised $p$-nitroaniline is selected for the procedure.

\section{Effect of base}

The preliminary experiments have shown that tetracycline can give coloured dye with diazotised $p$-nitroaniline only in basic medium. Therefore, different bases are tested for the optimal performance. The results show that maximum colour development is attained over the $\mathrm{pH}$ range $12-13$. This $\mathrm{pH}$ range is achieved only when $\mathrm{NaOH}$ and $\mathrm{KOH}$ are used. When $\mathrm{CH}_{3} \mathrm{COONa}, \mathrm{NH}_{4} \mathrm{OH}, \mathrm{Na}_{2} \mathrm{CO}_{3}$ and $\mathrm{NaHCO}_{3}$ are used, the colour contrast is very weak or the solutions are turbid. Therefore, $1 \mathrm{ml}$ of $5 \mathrm{M} \mathrm{NaOH}$ (final pH 12.2) is selected for the subsequent experiments. It can experimentally be observed that only with the strong bases, $\lambda_{\text {max }}$ can attain a constant value.

\section{Effect of surfactant}

The effect of several types of surfactants on color intensity of the dye in different amount has been investigated (Table 3). 
Table 3: Effect of surfactant on absorbance

\begin{tabular}{|c|c|c|c|c|c|c|c|c|}
\hline \multirow{2}{*}{ Surfactant used } & \multicolumn{6}{|c|}{ Absorbance/ml of surfactant added } \\
\cline { 2 - 9 } & \multicolumn{2}{|c|}{0} & \multicolumn{2}{|c|}{1} & \multicolumn{2}{|c|}{3} & \multicolumn{2}{|c|}{5} \\
\cline { 2 - 9 } & $\mathrm{A}$ & $\lambda_{\max }$ & $\mathrm{A}$ & $\lambda_{\max }$ & $\mathrm{A}$ & $\lambda_{\max }$ & $\mathrm{A}$ & $\lambda_{\max }$ \\
\hline CPC (10 & $-\mathbf{3})$ \\
\hline $\begin{array}{c}0.08 \\
\text { SDS (1\%) }\end{array}$ & 441 & 0.300 & 569 & 0.326 & 569 & 0.325 & 569 \\
\hline $\begin{array}{c}0.08 \\
\text { Triton X-100 } \\
(\mathbf{1 \% )}\end{array}$ & $\begin{array}{c}0.08 \\
3\end{array}$ & 440 & 0.083 & 440 & 0.094 & 441 & 0.084 & 441 \\
\hline
\end{tabular}

The results above show that the addition of CPC increases the intensity of dye and improves the colour contrast (a four-fold increase in intensity). Therefore, $3 \mathrm{ml}$ of $10^{-3} \mathrm{M}$ CPC solution has been used in subsequent experiments.

\section{Order of surfactant addition}

The order of CPC addition has been examined (Table 4).

Table 4: The order of CPC addition

\begin{tabular}{|c|c|c|c|c|}
\hline \multirow{2}{*}{$\begin{array}{c}\text { Order of } \\
\text { addition }\end{array}$} & \multicolumn{4}{|c|}{ Absorbance/min. standing time } \\
\cline { 2 - 5 } & 0 & 5 & 15 & 30 \\
\hline I & 0.250 & 0.251 & 0.252 & 0.251 \\
\hline II & 0.285 & 0.285 & 0.286 & 0.286 \\
\hline III & 0.320 & 0.325 & 0.326 & 0.326 \\
\hline
\end{tabular}

$\mathrm{I}=$ Tetracycline (A)+CPC (C)+ Diazotized $p$-nitroaniline (R)+ Base (B)

$\mathrm{II}=\mathrm{A}+\mathrm{R}+\mathrm{C}+\mathrm{B}$

$\mathrm{III}=\mathrm{A}+\mathrm{R}+\mathrm{B}+\mathrm{C}$

From the results above. Order III is recommended in the following experiments.

\section{Absorption Spectra}

When a solution of tetracycline is mixed with diazotised $p$-nitroaniline in a highly basic medium, a violet coloured azo dye is formed immediately. Fig. 1 shows the absorption spectra of the coloured azo dye and the corresponding reagent blank. The wavelength of maximum absorption at $569 \mathrm{~nm}$ has been adopted in all subsequent work. 


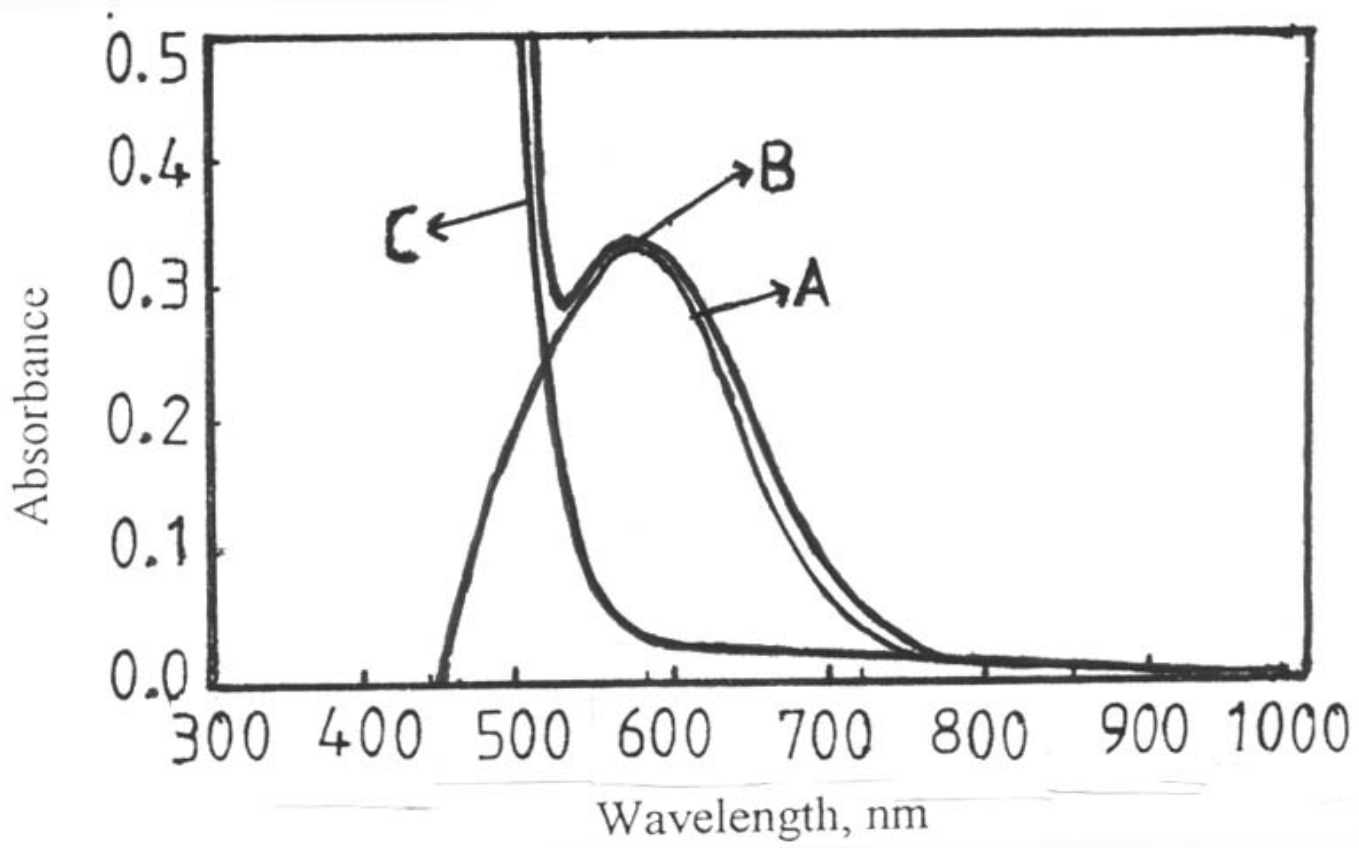

Fig. 1: Absorption spectra of $50 \mu \mathrm{g}$ tetracycline / $25 \mathrm{ml}$, treated according to the recommended procedure and measured against (A) blank (B) distilled water and (C) blank measured against distilled water.

\section{Recommended Procedure and Calibration Graph}

To a series of 25-ml volumetric flasks are added aliquots of solution containing 2 to $400 \mu \mathrm{g}$ tetracycline. About $5 \mathrm{ml}$ of distilled water, $5 \mathrm{ml}$ of $5 \mathrm{mM}$ diazotised $p$-nitroaniline reagents are then added and the mixtures are shaken. Then $1 \mathrm{ml}$ of $5 \mathrm{M}$ sodium hydroxide and $3 \mathrm{ml}$ of $10^{-3} \mathrm{M}$ CPC solutions are added and the volume is made to the mark with distilled water. The absorbances are measured at $569 \mathrm{~nm}$ against the corresponding reagent blank using 1-cm matched cells. Fig. 2 shows a straight - line calibration curve indicating that Beer's law has been obeyed in the concentration range 2-400 $\mu \mathrm{g}$ of tetracycline in a final volume, $25 \mathrm{ml}$ (i.e. 0.08-16 ppm). A negative deviation from Beer's law is occurred beyond the upper determination limit. The molar absorptivity, at the wavelength of maximum absorption is $7.8 \times 10^{4} \mathrm{l} \cdot \mathrm{mol}^{-1} \cdot \mathrm{cm}^{-1}$, and Sandell's sensitivity index is $6.2 \times 10^{-3} \mu \mathrm{g} \cdot \mathrm{cm}^{-2}$. 


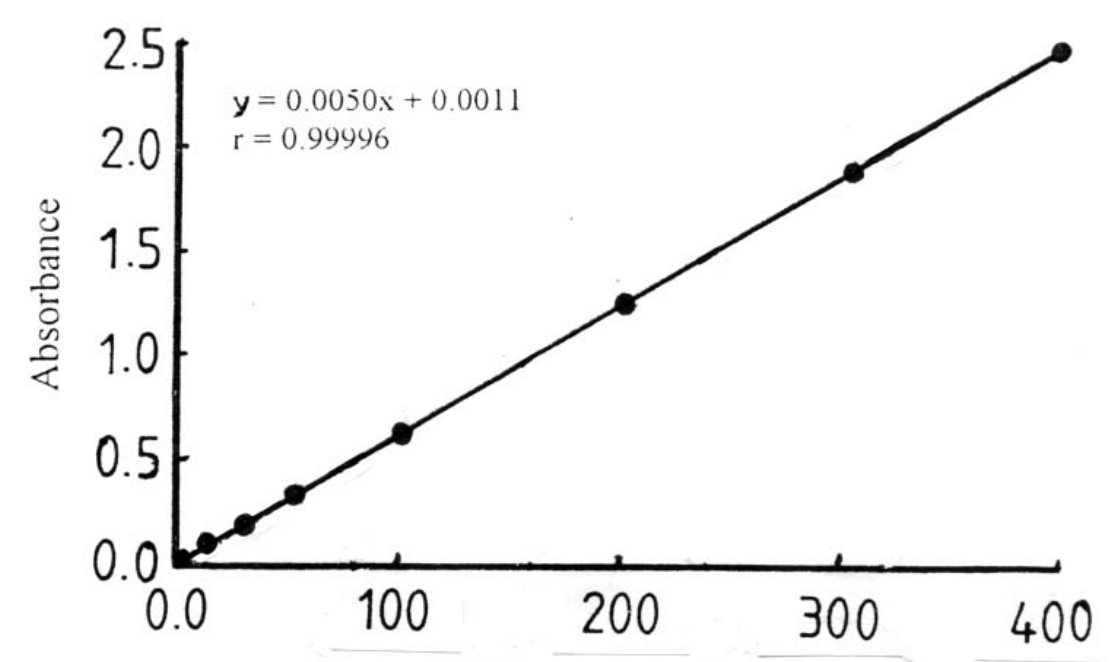

$\mu \mathrm{g}$ of Tetracycline / $25 \mathrm{ml} \mathrm{ml}$

Fig. 2: Calibration curve for tetracycline using diazotised $p$-nitroaniline.

\section{Accuracy and Precision}

To check the accuracy and precision of the method, tetracycline is determined at four concentrations. The results shown in Table 5 reveal that the accuracy and precision are quite satisfactory.

Table 5: Accuracy and precision

\begin{tabular}{|c|c|c|}
\hline $\begin{array}{c}\text { Amount of tetracycline } \\
\text { taken, } \boldsymbol{\mu g}\end{array}$ & $\begin{array}{c}\text { Relative error**, } \\
\mathbf{\%}\end{array}$ & $\begin{array}{c}\text { Relative standard* } \\
\text { deviation* } \%\end{array}$ \\
\hline 5 & 0.05 & \pm 0.12 \\
\hline 50 & 0.12 & \pm 0.25 \\
\hline 150 & 0.18 & \pm 0.24 \\
\hline 350 & 0.21 & \pm 0.15 \\
\hline
\end{tabular}

* Five determinations.

\section{Nature of the Dye}

The composition of the coloured azo dye has been established using Job's and mole-ratio methods (Fig. $3 \mathrm{~A}$ and B). The results show that the dye has been obtained by about 1:1 combining ratio of diazotised $p$-nitroaniline to tetracycline revealing a mono azo dye. The structure of the azo dye may be written as follows (Khider, 2001):

Reddishdye<smiles></smiles> 

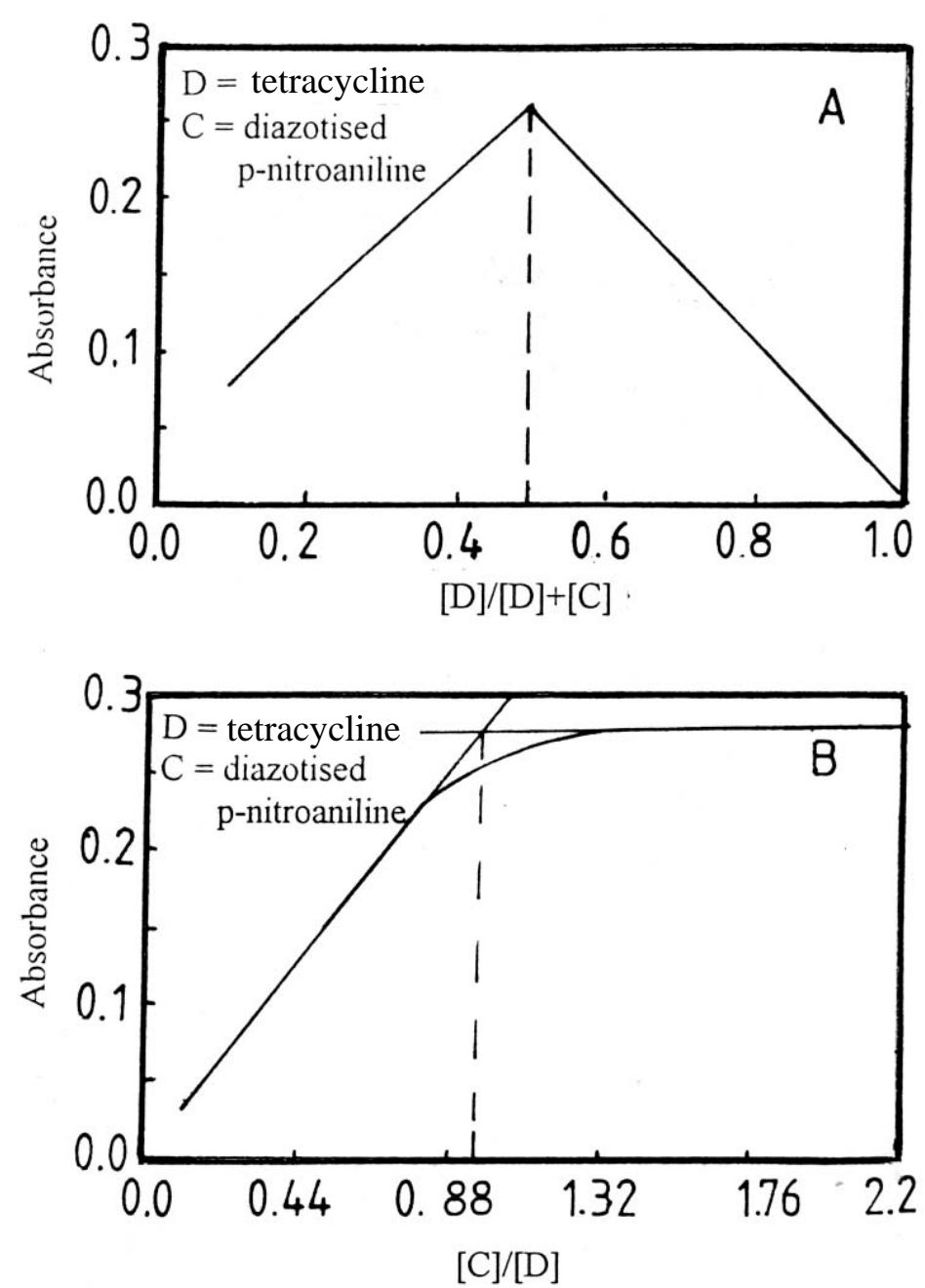

Fig. 3: (A) Job’s plot for tetracycline-diazotised p-nitroaniline azo dye.

(B) Mole-ratio plot for tetracycline-diazotised $p$-nitroaniline azo dye.

The apparent stability constant has been calculated by comparing the absorbances of solutions containing stoichiometric amounts of tetracycline and diazotised $p$-nitroaniline reagent with that containing an excess diazotised $p$-nitroaniline reagent under the optimal reaction conditions. The average stability constant is found to be $1.7 \times 10^{9} \mathrm{Molar}^{-1}$.

\section{Effect of Organic Solvents}

The effect of different solvents (water, ethanol, acetone, dimethylsulphoxide, 2methoxyethanol, methanol, propanol, acetic acid, formic acid, 1,4-dioxane, N,Ndimethylformamide and pyridine) was examined. Fig. 4 shows that water is a suitable medium from the point view of sensitivity and economy. 


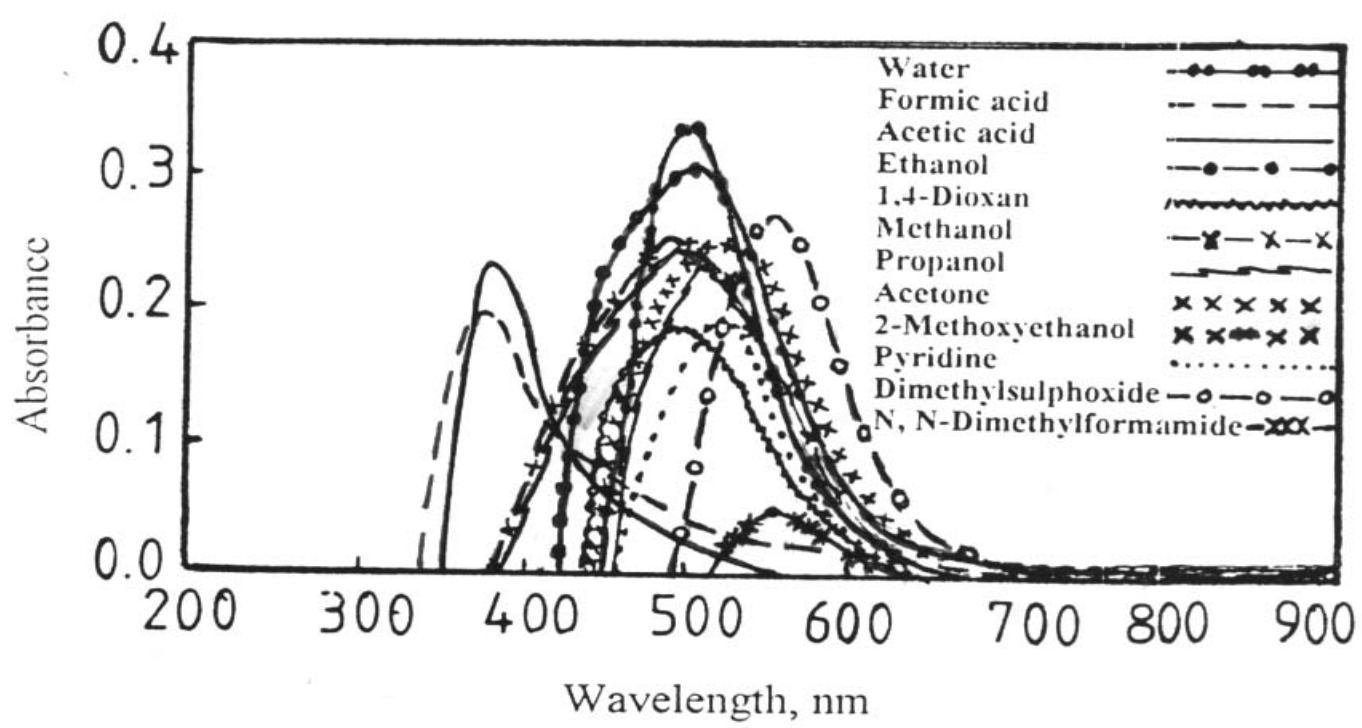

Fig. 4 : Effect of organic solvents on absorption spectra

\section{Application of the Method Assay of tetracycline in serum}

Tetracycline may be found in human blood following oral administration of capsule. After several treatments of serum, tetracycline has been determined following the recommended procedure. The results shown in Table 6, indicating good recoveries.

Table 6: Determination of tetracycline in serum

\begin{tabular}{|c|c|c|c|}
\hline \multirow{2}{*}{$\begin{array}{c}\text { Tetracycline } \\
\text { added, } \boldsymbol{\mu g}\end{array}$} & \multicolumn{3}{|c|}{ Recovery \% of tetracycline per ml of serum used } \\
\cline { 2 - 4 } & 0.1 & 0.3 & 0.5 \\
\hline $\mathbf{5}$ & 101 & 101 & 101 \\
\hline $\mathbf{5 0}$ & 99 & 101 & 100 \\
\hline $\mathbf{1 5 0}$ & 102 & 102 & 100 \\
\hline $\mathbf{3 5 0}$ & 102 & 100 & 102 \\
\hline
\end{tabular}

* Average of three determinations. 


\section{Assay of tetracycline in urine}

After extraction of tetracycline from urine with (3:2 petroleum ether-chloroform) and then stripping, the present method has been applied and the results, shown in Table 7, indicating good recoveries.

Table 7: Determination of tetracycline in urine

\begin{tabular}{|c|c|c|c|}
\hline \multirow{2}{*}{$\begin{array}{c}\text { Tetracycline } \\
\text { added, } \boldsymbol{\mu} \mathbf{g}\end{array}$} & \multicolumn{3}{|c|}{ Recovery \% of tetracycline per ml of urine used* } \\
\cline { 2 - 4 } & 1 & 3 & 5 \\
\hline 5 & 100 & 101 & 100 \\
\hline 50 & 99 & 101 & 100 \\
\hline 150 & 101 & 100 & 102 \\
\hline 350 & 99 & 98 & 99 \\
\hline
\end{tabular}

- Average of three determinations.

\section{Assay of tetracycline in ointment}

Several aliquots of the ointment solution have been taken and their tetracycline contents are determined using the recommended procedure. The results obtained are given in Table 8.

Table 8: Determination of tetracycline in ointment

\begin{tabular}{|c|c|c|}
\hline \multirow{2}{*}{ ml of ointment solution } & \multicolumn{2}{|c|}{ Tetracycline \% in ointment* } \\
\cline { 2 - 3 } & Skin ointment & Eye ointment \\
\hline 1 & 3.05 & 0.98 \\
\hline 2 & 3.02 & 1.08 \\
\hline 5 & 2.98 & 1.02 \\
\hline 10 & 3.07 & 1.05 \\
\hline
\end{tabular}

* Average of three determinations.

The mean value of the tetracycline content in the skin ointment is 3.03\% and in the eye ointment is $1.03 \%$ which agrees satisfactory with $3 \%$ and $1 \%$ labelled values. 


\section{Assay of tetracycline in vivo (serum and urine)}

After oral administration of capsule (500 mg), (Hoeohst) tetracycline has been determined in serum and urine at different times. The following table shows comparison of the present method with the standard GC method (British pharmacopoeia. 1980). A Pye Unicam Philips PU-4550 gas chromatograph, with hydrogen carrier gas and ionisation detector are used.

Table 9: Determination of tetracycline in vivo (serum and urine) and comparison of the present method with standard GC method

\begin{tabular}{|c|c|c|c|c|}
\hline \multirow{2}{*}{\begin{tabular}{c} 
Time after \\
administratio \\
\multirow{2}{*}{ min. }
\end{tabular}} & \multicolumn{4}{|c|}{ Tetracycline content, $\mu$ g/ml } \\
\cline { 2 - 5 } & Blood serum & \multicolumn{2}{c|}{ Urine } \\
\cline { 2 - 5 } 15 & 10.0 & 9.50 & 5.00 & 3.50 \\
\hline 30 & 32.9 & 31.1 & 16.6 & 15.8 \\
\hline 45 & 35.3 & 34.2 & 26.6 & 25.5 \\
\hline 60 & 36.8 & 35.1 & 36.8 & 35.2 \\
\hline 120 & 31.4 & 29.5 & 53.9 & 53.0 \\
\hline 180 & 30.6 & 28.9 & 59.7 & 57.2 \\
\hline 300 & 29.9 & 27.9 & 53.9 & 52.1 \\
\hline 360 & 15.4 & 14.4 & 51.5 & 49.0 \\
\hline 400 & 7.10 & 6.90 & 30.7 & 29.1 \\
\hline
\end{tabular}

Recoveries range are 102.9-106.4\% for blood serum and 101.7-105.5\% for urine.

The drug is absorbed after 10 min from administration and it can be extracted from the blood by the kidney after 15 min. (Robert, 1987).

\section{Validity of Method}

In order to test the result of the existence of a systematic error, the " $t$ "-test is used. The results of the present spectrophotometric method are compared with the standard GC method. Five replicate analysis are performed for the sample by each method. The $t_{\exp }$ is calculated using the following equation (Al-Hadidi, 1997):

$$
\begin{aligned}
& \mathrm{t}_{\exp }=\frac{\overline{\mathrm{d}}}{\mathrm{S}_{\mathrm{d}}} \sqrt{\mathrm{n}} \\
& \mathrm{S}_{\mathrm{d}}=\text { the standard deviation of the differences. } \\
& \mathrm{n}=\text { the number of five measurements. } \\
& \overline{\mathrm{d}}=\text { the mean of the differences. }
\end{aligned}
$$


The statistical value of t-test at 95\% confidence level for 5 degrees of freedom is 2.776. Thus, it is concluded from the result that the 1.817 calculated value of $t_{\exp }$ is < 2.776, Thus indicating that no systematic error has occurred. Therefore, the present method has good validity.

\section{CONCLUSION}

A simple, rapid and sensitive spectrophotometric method for the determination of trace amounts of tetracycline in aqueous solution has been developed. The method is based on coupling of tetracycline with diazotised $p$-nitroaniline reagent in basic medium to form a violet mono azo dye that is water-soluble, stable and shows maximum absorption at $569 \mathrm{~nm}$. Beer's law is obeyed over the range 2-400 $\mu \mathrm{g} / 25 \mathrm{ml}$ i.e. 0.08-16 ppm with a molar absorptivity of $7.8 \times 10^{4} \mathrm{l}_{\mathrm{mol}} \mathrm{m}^{-1} \cdot \mathrm{cm}^{-1}$ and Sandell sensitivity index of $6.2 \times 10^{-3} \mu \mathrm{g} \cdot \mathrm{cm}^{-2}$. The method is applicable to the determination of this compound in serum, urine and pharmaceutical preparations (Tetracycline skin and eye ointment and capsules).

\section{REFERENCES}

Al-Abasi, K.M.H., 1999. Spectrophotometric Applications of Diazometry to the Determination of Some Pharmaceuticals and Toxics, Ph.D. Thesis, College of Science, University of Mosul-Iraq, pp.64-65.

Albert, A., 1980. Selective Toxity and Related Topics, 4th Edn., Bannes and Nabel, New York. 95p.

Al-Hadidi, N.R.A., 1997. Development of Spectrophotometric Methods for Determination of Copper in Various Samples and Comparison with Different Analytical Techniques, Ph.D. Thesis, College of Science, University of Mosul, Iraq. 39p.

Ali, N., and Mohammad, S., 2006. Parallel Factor Analysis and Partial Least Squares Applied to Spectrophotometric Determination of Tetracycline in Pharmaceutical Formation and Biological Fluids, Chemical and Pharmaceutical Bulletin J. 54(5): pp.711-713.

Al-Mollah, L.A.M., 1986. Studies of Some Metabolic Effects of Noradrenaline, Insulin in Presence of $\mathrm{Ca}^{++}$, M.Sc. Thesis, College of Science, University of Mosul, Iraq. pp.25-26.

Alwan, A.A.S., and Abou, Y.Z., 1990. Iraqi Drug Guide, National Boand for the Selective of Drugs and Central Drug Information Burean, Baghdad, pp.112-113.

British pharmacopia, 1980. Her Majestry Stationary Office, London. 1: 17p.

Guyton, A.C., and Hall, J.E., 1996. Textbook of Medical Physiology, 9th Edn., W.B. Saunders Company, American. 327p.

Jan, K., 1980. Spectrophotometric Determination of Salicylic Acid After Extraction with Isopropyl Alcohol and Sodium Hydroxide, Sarm politeness, 36, pp.281-283.

Khider, N.S.O., 2001. A Centinued Investigation of Spectrophotometric Diazometry, Ph.D. Thesis, College of Science, University of Mosul-Iraq, 108p.

Robert, E., 1987. Biopharmaceutices and Clinical Pharmacokinetics, 4th Edn., Marcel Dekker, Inc. New York, 102p. 
Saisunec, L., Boon, L., and Surasak, W., 2006. Flow Injection Spectrophotometric Determination of Tetracycline by Complexation with Aluminium (III), Anal. J. Sci., 22(1), pp.15-19.

Sultan, S.M., 1986. Spectrophotometric Determination of Tetracycline with Sodium Molybdate, Analyst, 111, pp.97-99.

Talaro, K., and Talaro, A., 1996. Fondations in Microbiology, 2nd Edn. WCB Publishers, Dubuque, IA. 366p.

Wilson, C.O., Gisrold, O., and Doerge, R.E., 1977. Textbook of Organic Medical and Pharmaceutical Chemistry, J.B. Lippincott Company, New York, 134p.

Younis, Th.I., 1994. Photometric Assay of 1-Naphthylamine by Azo Coupling, M.Sc. Thesis, College of Science, University of Mosul-Iraq, pp.45-49. 